\title{
得法の一考察
}

\section{周柔 含}

1. 問題の所在 心不相応行法の得（prāpti）は有情と法との帰属・離繫関係を 成立させる働きをもち，有情に法が成就していることを証明する法体である。こ の法体を通して有情は自らに所属する法に連慗するから「得の縄」と言われ，ま た，それは有情が聖者であるか異生であるかを識別する重要な標記となる。

有部 (Sarvāstivādin) は心不相応行が実有であると主張し，譬喻者（Dārșțāntika） 及び経部 (Sautrāntika) の批判を浴びた（T27, 198a15-17)。初期仏教において得法の 概念があるのであろうか。もしあるとするならば，それは阿毘達磨時代の得法の 用法と同じであろうか。なぜ有部は得法を成立させなければならないのであろう か. 批判を浴びた有部は如何に得法の実有性と必要性を証明したのであろうか.

得法の作用について，毘婆沙師は建立因（vyavasthāhetu）説を提示し，悟入 ( ${ }^{*}$ Skandhila）は称説因説を主張し，衆賢（Samghabhadra）は不失法因 (dharmāvipraṇāśakārana) • 智幖幟（jñānacihna）との二作用説を提出している，伝統有部はすでに建立因説を 立てているのに，なぜ䍃賢はまた二作用説を提出するのであろうか. 本稿では論 師間の得法の実有性への批評・論証を通して，有部が如何に得法の実有性を証明 し，得法の実有性を主張したのかという由来を検証しようとするものである。

2 . 得と非得『舎利弗阿毘量論』における心不相応行法の八法には「得果」 は立てられるが，得法は説かれていない，得果とは獲得している聖果を失わない 心不相応行法である。初期仏教には得法は成立していないが, 福田环氏の研究 (「初期経典に見られる“得”の用例」『印仏研』40-1, 1991・12)によれば初期仏典におけ る得（pra $\sqrt{\mathrm{a} p}$ ）の用法は広く修行聖果の獲得及び修行の最終目標（涅槃）の達成に 使われているという，得法の成立は修道論と密接な関わりがあることが分かる.

得法は最初に『法繿足論』・『品類足論』の心不相応行の十六法に現れている. 『阿毘量甘露味論』になって，その十六法に『発智論』の心不相応行の「異生性」 (prthagjanatva；凡夫性）を加え十七法となる。『阿昆最心論』以降には「依得・事 得・処得」の三法を得法に収め十四法となる.そして『俱舎論』に至って世親は 
元の凡夫性（異生性）を捨て，「非得」を立て，現在通説の十四法となっている.

一方, 初期論書 (T26,392c22-393a5；464c20-26) には聖果の獲得の他に断惑によっ て涅槃——択滅」(pratisamphyā-nirodha) 一の獲得が見られる。従って得法の用 法は修道論・断惑論に深く関連性があることが分かる.つまり得法の用法は聖道 の「得果」から煩悩の消滅状態 (択滅) に拡大解釈されたことが了解される。

2.1.「得」得には二種類があり，〔一つは〕未だ得ていないものを〔初めて獲 得すること，或は]既に失ったものを[再び]獲得することであり，〔もう一つは] 既に獲得したものの成就である $\left(\mathrm{AKBh}, 62_{16}\right)$. 前者は獲（lābha）といい, 後者は 成就（samanvāgama）という。

では，得・獲・成就とは，同義或いは異義であろうか. 称友（Yaśomitra）は， 「得（prāpti）は総名であり，獲（lābha）と成就（samanvaya）は別名である，獲（lābha） と獲得（pratilambha）とは同義であるのを言う時に成就（samanvaya）及び同随 (samanvāgama) とは異なるのではない」と説いている（AKVy, 143 10-11）。

これら（得・獲・成就）は同義異語といえども〔獲・成就〕をもって〔得〕を 定義するのは適切ではない，Abhidharmadipa（86, $）$ には，得とは成就であり，獲 であり，〔有情が〕法を有することを建立するものである，と説かれる。簡単に 言えば，得の概念において，得はすなわち成就・獲であり，得の条件において は，得とは有情が法を成就していることを証明する法体である。つまり，心不相 応行の得法は, 一般の獲得の概念と違い, 特殊な意味も持ち, 有情への法の帰属 関係を建立する法体である。

要するに，初期部派の得法は聖道の獲得・断惑の証滅（択滅）に使われ，後期 に至って有情自身と相続する法（有漏・無漏等）との関わりに拡大し，有情自身 に関わる法は得という法体がなければならないと分かる（T26, 1008a9-b12）。

2 ．2．「非得」得には二種類がある．同様に非得にも二種類がある，一つは獲 得していないものであり，もう一つは獲得したが既に失ったものである.『俱舎 論』には「云何異生性? 謂不獲聖法. 不獲〔聖法〕, 即是非得異名」(T29, 23b1819）とある。換言すれば，聖道の非得すなわち異生性である。要するに聖道の非 得の前提において, 非得は異生性の異名である。これが，世親が元の凡夫性（異 生性）を捨て，非得を建てた理由であろう。なぜならば，聖道の非得の意義にお いて異生性を説明することができ，別に異生性を立てる必要がないからである。

得・非得は文字の意味から対立した概念である。しかし，以上の検討を通し て，得・非得はそれぞれ特別な意義をもっている，得法は有情への法の帰属関係 
を建立する法体であり，非得は聖道の非得という前提において，異生性の異名で ある。特に，非得の用法は聖道の非得のみに限定されている.

3.「得」の実有性 毘婆沙師は聖教量を引用し得法の実有性を証明している $\left(\mathrm{AKBh}, 63_{3-5}\right)$ ，例えば契経に説かれたように無学聖者は十無学法の生起によって 十無学法を獲得し, 相続にその法を具有することによって五上分結を断じ〔無学〕 聖者となる，つまり，生起・獲得・成就を通して得法の実有性が理解される。

譬喻者にとって，毘婆沙師の説明はただ実質のないような空論の概念であり， 名称上の方便の施設（prajñapti）にすぎず，真実法ではないのである，喻えば，五 指を握って拳と称し，手を開いて，非拳と言うようなものである（T27, 479a21-24）.

また，もし有部の「相続に法を有する」という説に従い，成就の実有性を主張 するならば，大過失があると世親は指摘している，例えば，転輪聖王が七宝を有 している場合, 有情法を成就し, 非有情法（例：輪宝）をも成就し，更に他身の 相続する法（例：女宝）をも成就してしまい，過ちを犯すことになるからである という $\left(\mathrm{AKBh}, 63_{5-7}\right)$ ）なぜならば，得法は有情法及び二滅（択滅無為・非択滅無為） を成就し, 非有情法を成就しないし, 自身の相続する法を成就し, 他身の相続す る法を成就しないからである(AKBh, $62_{17-22}$ ).

さて，世親の非難について，その批判は成り立たないと衆賢は回答している．な ぜならば，輪王が七宝を成就しているというのは，七宝を支配しているという意 味である，それは輪王が七宝に対する自在力であり，増上果である．宝が現前に 現れる際に成就するというから，上述の過失はないのである（T29,397a16-20).

世親は問難を続け，それなら如何に得法の実有性を確かめるのであろう。衆賢 は契経を挙げ，「契経には，補特伽羅の悪法が現前する際に，善法は断じられた のではなく，ただ隠没したのである」(T27,79b21-24)，また「補特伽羅は善法及 び不善法を成就していることを知るべきである」と説いている（T29, 397a12-15）. もし得法が実在するものでないならば，如何に上記の契経を説明するのであろう か.つまり, 有部は教証を通し, 得法の実有性を主張している.

4. 依「用」証「体」毘婆沙師は教証によって得法の実有性を証明したにも かかわらず，それは不合理である，と世親から非難を浴びた。

〔もし得が塞有であるとすれば〕次のような不合理がある。この（得）の自性は色・声 等のように, 或いは貪・贔のように知られないから, 又〔得の]作用も眼〔根〕・耳＼cjkstart根〕 のように〔知られないから〕，それ故〔得が色法・心所のように個別の】実体としている 法であることは不可能なので，〔得が実有であることは〕理に合わない.（AKBh, 63 8-10 $_{10}$ ) 
つまり，得は直接知覚（pratyakșa）或いは推理（anumāna）の認識手段を通して 把握されないから，実有性を証明することはできないのである。それゆえ，もし 得が色法・心所等のように実有であると主張するならば，不合理となるのであ る.では，有部は如何に得法の実有性を証明するのであろうか.

4.1. 毘婆沙師の建立因説 三世実有の論証において毘婆沙師は世友の「位有 異」説を認許し，三世の位の違いは法体の作用が相違するからであるとする。そ れ故, 得の実有性をも作用を通して証明させることが出来るのである，得の作用 は聖者・異生の差別を建立する建立因であると毘婆沙師は主張している．現実の 状況から言えば，もし得がなければ異生・聖者が有漏心を起こした場合, 誰が聖 者であり誰が異生であるのか, その差別を立てることができなくなるので修道の 混乱を造成してしまうのではないか, と有部は強く主張している（T27,479b20-24）。

有部の回答について，世親は，煩悩の断滅の有無によって〔聖者と異生は〕区 別される，と言い返した $\left(\mathrm{AKBh}, 63_{16-17}\right)$ 。しかしながら，有部の断惑理論によれ ば，まず煩悩を縛る得法を断じ，そして離繫得（visamyogaprāpti）を獲得するとい う順序がある（T27, 796c28-797a1; 拙稿「説一切有部的断惑理論」2009年). 言い換え れば，断惑に基づいて聖者・異生の差別を立てると雖も，得がなければならない のである。もし得が実有ではないと主張するならば，如何に煩悩の得の有無に よって異生・聖者を判別するのであろうか. したがって, 得がある故に, 初めて それ（断惑の有無）が成り立つのである(AKBh, $\left.63_{17-18}\right)$.

4.2. 悟入の称説因説 衆賢の師悟入の『入阿毘達磨論』には次のように説か れている．「補特伽羅が善・悪・無記法を有すると称説する因は得であり，獲・ 成就とも言われる。得とは補特伽羅が法を有することを証明する法体である」 (T28,986a29-b2)，悟入は果によって因を推理し得の害有性を説明したのである.

4.3. 菜賢の不失法因・智幖幟説 得の実有性を明らかにするために，衆賢は 二作用説を提出した，得が実有であることは理に合わないことはない．なぜなら ば，得は実有であるとする理由があるからである，一，得は獲得した法を失わせ ない原因であり，すなわち不失法因である。たとえ聖者が有漏心を起こしても， 聖法は存続しつつあり, 失われたわけではないから, 彼は聖者であり, 異生では ないのである。二, 得は「彼（能得法）に此（所得法）が所属している」という知 の幖幟，すなわち智幖幟である．例えば，有情に聖道が所属しているというよう に，人はその有情に対して，「彼は〔部分の〕煩悩を断じ，聖者であり，異生で はない」との知が生ずるのである（T29, 397b3-5；123a2-124b3）. 
加藤宏道氏（「得・非得の定義」『印仏研』32-2, 1984・3）は，衆賢は認識と存在の 作用を通して，得の実有性を証明したのである，と述べている。

5.「得」の作用説 得の作用について, 加藤宏道氏は次のような意見を述べ ている.（1）『入阿毘達磨論』の称説因は『順正理論』の智幖幟に相当する，(2) 断惑の立場において，智幖幟説を立てるだけで建立因説を包含したのである， （3）得の作用において，智幖幟説はすでに得の作用性を説明し，別に建立因説を 説くのは修道論のためである, と加藤氏は指摘している.

もし智幖幟だけで得の作用を充分に説明することができるならば，なぜ衆賢は 不失法因を挙げるのであろうか。 また，建立因説は本来伝統有部の主張であるの で，建立因説を別説と見なすべきではない，問題は，伝統有部が既に建立因説を 立ているのに，なぜ衆賢がまた二作用説を挙げたのであろうか。

5.1. 恒に有情法と俱生する 毘婆沙師の得の建立因説は世親によって批判さ れた．もし得がなければ何によって聖者・異生の差別は立てられるのであろうか.

所依（āśraya）が違うから，それ（煩悩の已断・未断の差別）が成り立つのである。 な ぜならば，聖者たちは見〔道〕・修道によって〔見修惑を断じ〕、見修〕所断の煩恼が 再び生ずることがないように，所依が変ぜられたからである，それゆえ，恰も〔火に〕 焼かれた穀子のように，〔ある者の〕所依は煩悩の種子でなくなった時に，或いは世間 道によって〔煩悩の〕種子が損害された時にも，「煩悩已断者」と言われる。〔それと〕 相反して，煩悩未断者〔と言われる〕。し[煩悩が〕未断であるならば，〔彼は〕それ (煩悩の種子) が成就している者であり，もし〔煩悩が〕已断であるならば，〔彼は〕そ れ（煩悩の種子）が成就していない者である，と仮立される(AKBh, 63 18-21 $)$.

世親によれば，聖者・異生の区別は所依の違いであり，すなわち煩㥗の種子の 有無によるのである，所依が変ぜられたとは，恰も火に焼かれた款子のように， 種子が損害され，芽を出すことがないことである．簡単に言えば，煩悩の種子が なければ煩悩已断と言われ，聖者となるのである．

ここには二つの問題が関わっている．まず断惑の問題である．世親は煩悩の種 子が損害されれば断惑であると主張している。しかし有部にとって「離繫は必ず 断惑であり，断惑は必ずしも離繫ではない」(AKBh, $\left.307_{18-19}\right)$ ，つまり煩悩の繫縛 を断じるだけではなく，能縁・所縁煩悩の繋縛を離れることこそが断惑である.

有部の宗旨では諸法は三世実有である，したがって，煩悩と有情との縏がりで ある得法を断じることができるとは言え，煩悩を永遠に消滅することはない，そ れが衆賢が得の不失法因を提出する主な理由であると筆者は考えている。『順正 理論』に「令所得數容更起, 成不失因, 説名為得」(T29,499c5-6) と説かれている. 
得は有情と法との帰属・離繫関係を成立させる法体である．不失法因はその所属 関係の相続性という得の働きを示しているのである.

次に，第二の問題も断惑論に関わる，経部の主張によれば，世俗道は煩悩を伏 せるだけで，煩恼を断じることができない。換言すれば，もし因縁が俱足した場 合，また現行（芽が出る）してしまう。もし煩恼の種子が損害されたならば，再 生する可能性はないはずであり，その後煩悩の芽が再生してしまうのならば，種 子が損害されたとは言えないし，煩悩を断じたとは言えないのである（T29, 398b39)。それゆえ，衆賢は次のように説いている。「経主の種子説は，自説の理に合 わない，得とは既に得ている法を失わせない原因（不失法因）であり，また法が 有情に所属しているという識別標記（智幖幟）である」(T29,398b20-24）。この二 つの機能によって得の実有性を証明することができる。

5.2 . 認識と存在 得と断惑について, 加藤氏は, 得が存在しないならば, 聖 者・異生の煩悩の已断・未断を知る標幟がなくなり, 聖者と異生とを建立するこ とができなくなると説いていることからしても，建立因は智幖幟に含まれると言 える，と指摘している（加藤前揭論文, 註 5).

筆者は，衆賢の智幖幟或いは不失法因のいずれも，伝統の建立因説を離れてい ないと思う。なぜならば, 得は有情と法との帰属関係を成立させる法体である. 建立因説は，聖者・異生の差別(「認識」) を立てると共に，得法自体の存在（「存 在」）を表明し，得の実有性を証明するからである.

世親の論難に対して，衆賢の不失法因（既に得た法を相続し失わない）の提出は， 明らかに有部の得法の成立の由来を説明したものである.なぜならば，得は恒に 有情法と俱生するからである. そして, 智幖幟（彼の能得法に此の所得法が所属し ている）の提出は，有情と法との㷌属・離属関係を知らせるという識別の働きを 示すためである，要するに，衆賢は認識面と存在面との働きによって，得の実有 性を説明しており，昆婆沙師の主張と違わないのである.

しかしながら，伝統の建立因説は衆賢の二因説とは相違している．存在性にお いて両者とも得の実有性を説明しているが，方式が異なるのである．建立因は認 識手段を通して得の存在ということを説明し，不失法因は有部自宗の三世塞有説 を通して，得は恒に有情法と俱生することを強調しているのである.

そして，認識の作用において，得法の成立は修道論と関わるから，建立因説は 伝統の修道論・断惑論に基づいて提出されたもので,つまり有情に聖法を有して いるという事実を説明することを目的としている．しかし，後期の心不相応行の 
得法の働きは修道論を越え, 有情と有情法との関係に広がり, 有情が法を有して いるということを強調する．すなわちその働きは智幖幟の㗢きである．前者（建 立因）は凡聖の建立根拠を優先に考慮し, 後者（智幖幟）は有情と諸法との相続 関係を強調するのである.

最後に，如何にこれら得の作用説を考えるのであろうか. 櫻井良彦氏（「不失法 因・智幖幟としての得」『仏教学研究』58・59, 2003・3） は加藤氏の見解——邓阿毘 達磨論』の称説因は『順正理論』の智幖識に相当する一一に同意し, 更に Abhidharmadipa も得の智幖幟・称説因を継承しているとする。一体, Abhidharmadipa の作用説と智幖幟・称説因との三者は如何なる関係にあるのであろうか.

Dīpakāraによる得の定義とは，〔得に基づいて，有情にこの〕法を有するとい うことを建立（vyavasthiti）させるものである $\left(\mathrm{ADV}, 86_{9}\right)$. vyavasthiti は自然にvyavasthāhetu（建立因）を想起させる。一方，得とは有情が法を成就していることを 証明する法体である。このような定義は『入阿毘達磨論』の得の称説因一一有情 が法を有することを称説する因一と同じであり，また得の智幖幟——そ（能 得法）にこの (所得法) が所属している—の働きと一致している.

以上の関係により, 悟入の称説因, Dippakāra の建立因及び衆賢の智幖幟は, 有 情が法を有する (果) という知的な働きによって得（因）の実有性を説明したの であるから，有部伝統の建立因との相違のないことが明らかになる。つまり不失 迲因の外にこれら得の諸作用には，認識作用によって得の実在性（存在）を説明 するという点が共通することが注意される. 認識論は有部の三世実有説を成立さ せる重要な根拠であり，有情が法を有していることを知る（認識）ためには，「境」 が存在していることが必要である，要するに，認識作用に基づいて法の存在自体 が説明されるから，それは伝統昆婆沙師の建立因説と一致することが分かる.

6. 結論 紙幅の都合上, 結論については本論中の下線部を参照されたい.

〈略号幖〉 AKBh. Abhidharmakośabhāsya of Vasubandhu. Ed. P. Pradhan. Patna: K. P. Jayaswal Research Institute, 1967. AKVy. Sphuțârthā Abhidharma Kośavyākhyā. Ed. U. Wogihara.

Tokyo:Sankibo, 1989. ADV. Abhidharmadīpa with Vibhāṣāprabhāvrtti. Ed. P. S. Jaini.

Patna: K. P. Jayaswal Research Institute, 1977.

〈キーワード〉得法, 建立因, 不失法因, 智幖幟, 称説因, 断惑論 (慈済大学宗教与人文研究所副教授) 